\title{
Co-expression of Fas and Fas-ligand on the surface of influenza virus-infected cells
}

\author{
Ippei Fujimoto', Takenori Takizawa ${ }^{2}$, Yoshiki Ohba ${ }^{1}$ and \\ Yoshinobu Nakanishi ${ }^{1,3}$ \\ ${ }^{1}$ Faculty of Pharmaceutical Sciences, Kanazawa University, Kanazawa, Ishikawa \\ 920-0934, Japan \\ 2 Institute for Developmental Research, Aichi Human Service Center, Kasugai, \\ Aichi 480-0304, Japan \\ ${ }^{3}$ corresponding author: Faculty of Pharmaceutical Sciences, Kanazawa \\ University, 13-1 Takara-machi, Kanazawa, Ishikawa 920-0934, Japan. tel: 81- \\ 76-234-4424; fax: 81-76-234-4480; email: nakanaka@kenroku.ipc.kanazawa- \\ u.ac.jp
}

Received 11.6.97; revised 27.11.97; accepted 5.12.97

Edited by M. Piacentini

\begin{abstract}
Influenza virus-infected cultured cells undergo apoptosis after an increment of Fas (APO-1/CD95) on the cell surface. By flow cytometry, cell surface Fas-ligand was detected in virusinfected cells with a time course similar to that of Fas. Moreover, Fas and Fas-ligand were co-expressed in those cells. The mode of induction, however, appeared to be distinct for the two proteins. Influenza virus infection induced the externalization of phosphatidylserine on the cell surface at the early stage of apoptosis, an event that has been observed in cells undergoing Fas-mediated apoptosis. In fact, apoptosis of the virus-infected cells was inhibited in the presence of an antagonistic anti-Fas-ligand monoclonal antibody. These results suggest that influenza virus infection causes augmented expression of both Fas and Fas-ligand and apoptosis is induced when the infected cells come into contact with each other.
\end{abstract}

Keywords: apoptosis induction; influenza virus; Fas; Fasligand; phosphatidylserine externalization

Abbreviations: FITC, fluorescein isothiocyanate; MTT, 3-(4,5dimethylthiazol-2-yl)-2,5-diphenyl tetrasolium bromide; PI, propidium iodide; PS, phosphatidylserine

\section{Introduction}

Many viruses alter the regulation of apoptosis, either by stimulation or inhibition, in infected cells (Nakanishi, 1995; Teodoro and Branton, 1997). Clarifying the mechanism of this phenomenon could lead to the development of new therapeutics against virus diseases.

Influenza virus causes apoptotic death of cultured cell lines (Takizawa et al, 1993; Fesq et al, 1994; Hinshaw et al, 1994) as well as of tissues in infected animals (Mori et al, 1995). We previously showed that production of Fas (Peter et al, 1996; Nagata, 1997), also called APO-1 or CD95, increases at the transcription level in influenza virus-infected cells prior to their death (Takizawa et al, 1993, 1995). Since the addition of an apoptosis-antagonizing anti-Fas monoclonal antibody partly inhibited apoptosis of infected cells (Takizawa et al, 1995), it has been suggested that virus-induced apoptosis involves the Fas system. However, it is not clear whether the expression of Fas-ligand is also induced upon influenza virus infection. We here examined the presence of Fasligand on the surface of virus-infected cells using a monoclonal antibody against Fas-ligand, and the same antibody was used to influence apoptosis caused by the virus infection.

\section{Results}

\section{Co-expression of Fas and Fas-ligand on the surface of influenza virus-infected cells}

HeLa cells were infected with influenza virus, harvested at various time points and subjected to a flow cytometric analysis of cell surface Fas and Fas-ligand (Figure 1). In line with our previous observation (Takizawa et al, 1995), the amount of cell surface Fas increased at about 6-12 $\mathrm{h}$ after infection. Fas-ligand also became detectable on the surface of the virus-infected cells with a time course similar to that of Fas. The presence of a soluble form of Fasligand (Tanaka et al, 1995) was not likely since the addition of the cultured medium did not induce apoptosis of uninfected HeLa cells (data not shown). We next examined whether Fas and Fas-ligand are co-expressed in the virus-infected cells by doubly staining the cells with antibodies against the two proteins. As shown in Figure 2, more than $70 \%$ of the infected cells were positive for both Fas and Fas-ligand at $24 \mathrm{~h}$ after infection, indicating that both proteins are simultaneously expressed on the cell surface.

We previously reported that expression of the Fasencoding gene is stimulated without apoptosis induction when HeLa cells are cultured in the presence of poly(I)poly $(\mathrm{C})$, a synthetic double-stranded RNA (Takizawa et al, 1995). We examined whether the same effect is observed for Fas-ligand. Expression of cell surface Fas increased on the addition of poly(I)-poly(C) whereas that of Fas-ligand changed little (Figure 3 ). In addition, HeLa cells showed a basal level expression of Fas as previously observed, but this was not the case with Fas-ligand. These results explained why poly(I)-poly(C)-treated cells do not undergo apoptosis irrespective of an increment of Fas production, and indicated that the regulatory mechanisms underlying expression of Fas and Fas-ligand are distinct from each other. 
(A)

(h)

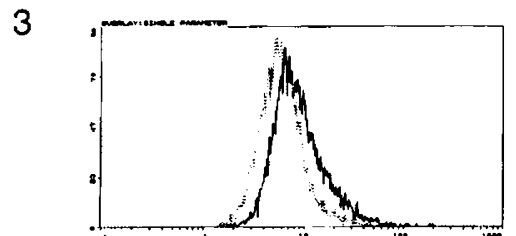

6

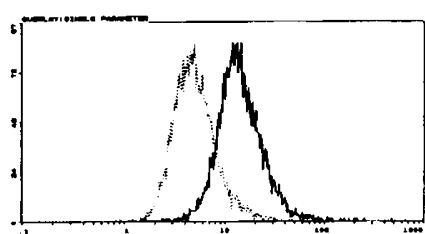

12

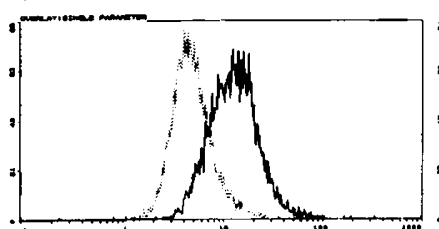

24

$\overline{0}$

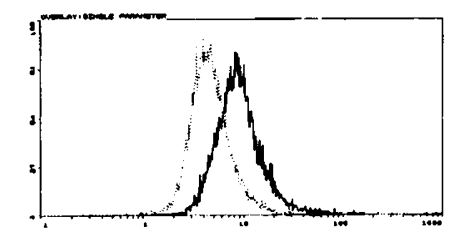

Fluorescence
(B)

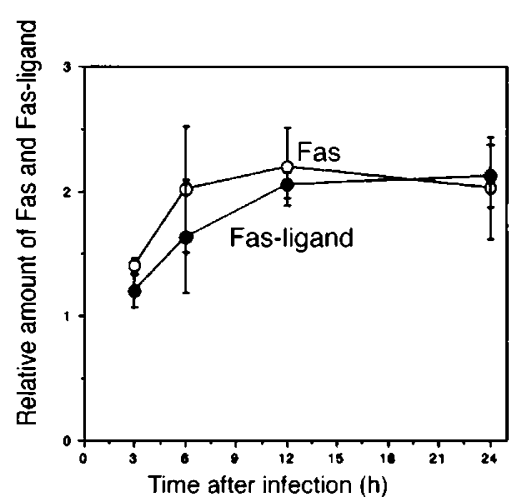

Figure 1 Cell surface expression of Fas and Fas-ligand upon influenza virus infection. HeLa cells were infected with the virus and examined for the presence of cell surface Fas and Fas-ligand by flow cytometry. (A) The virus-infected (solid lines) and mock (broken lines) cells were treated with an antihuman Fas antibody or an anti-human Fas-ligand antibody, and the cells bound by a primary antibody were detected with a FITC-conjugated secondary antibody. (B) Semi-quantitative representation of the amount of Fas (open circles) and Fas-ligand (closed circles) on the surface of the virus-infected cells. The mean fluorescence in the virus-infected cells was divided by that in mock cells, and the mean and standard deviations from three independent experiments are shown

Mock

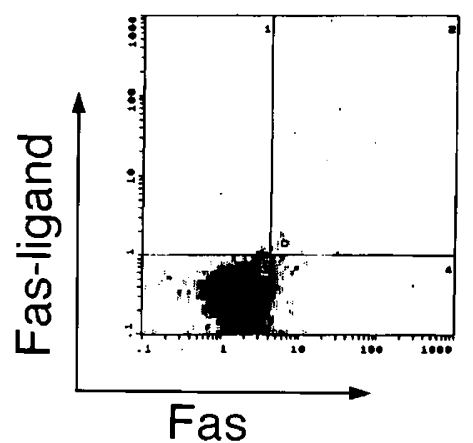

Figure 2 Co-expression of Fas and Fas-ligand in influenza virus-infected cells. HeLa cells infected with the virus for $24 \mathrm{~h}$ were subjected to a two-color analysis of Fas and Fas-ligand on the cell surface. Shown is a result from one experiment of many similar results

\section{Infected}

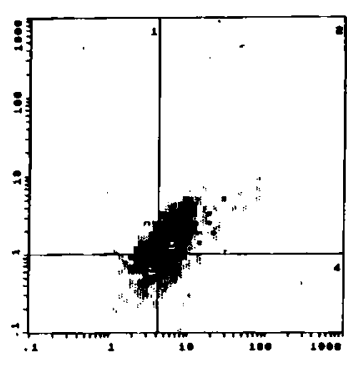

$\overline{\bar{\delta}}$
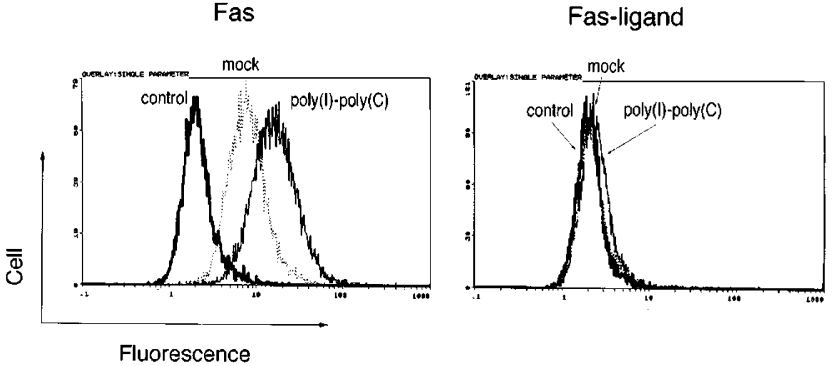

Figure 3 Effect of a double-stranded RNA on expression of Fas and Fasligand. HeLa cells were treated with poly $(\mathrm{l})-\operatorname{poly}(\mathrm{C})$ or a buffer alone (control, mock) and subjected to flow cytometric analyses of cell surface Fas and Fas-ligand, control, cells analyzed with no primary antibodies 
(A)

(h) 3
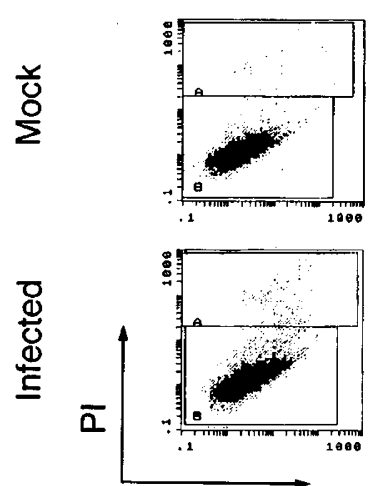

FITC

(B)
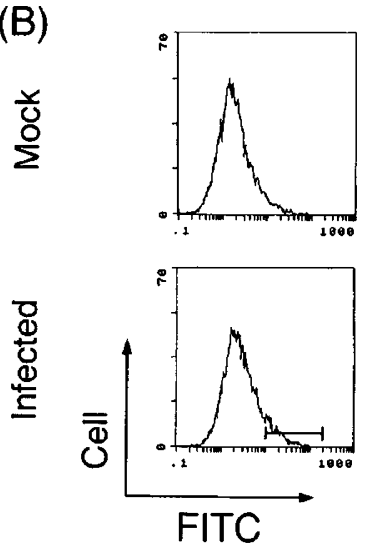

(C)
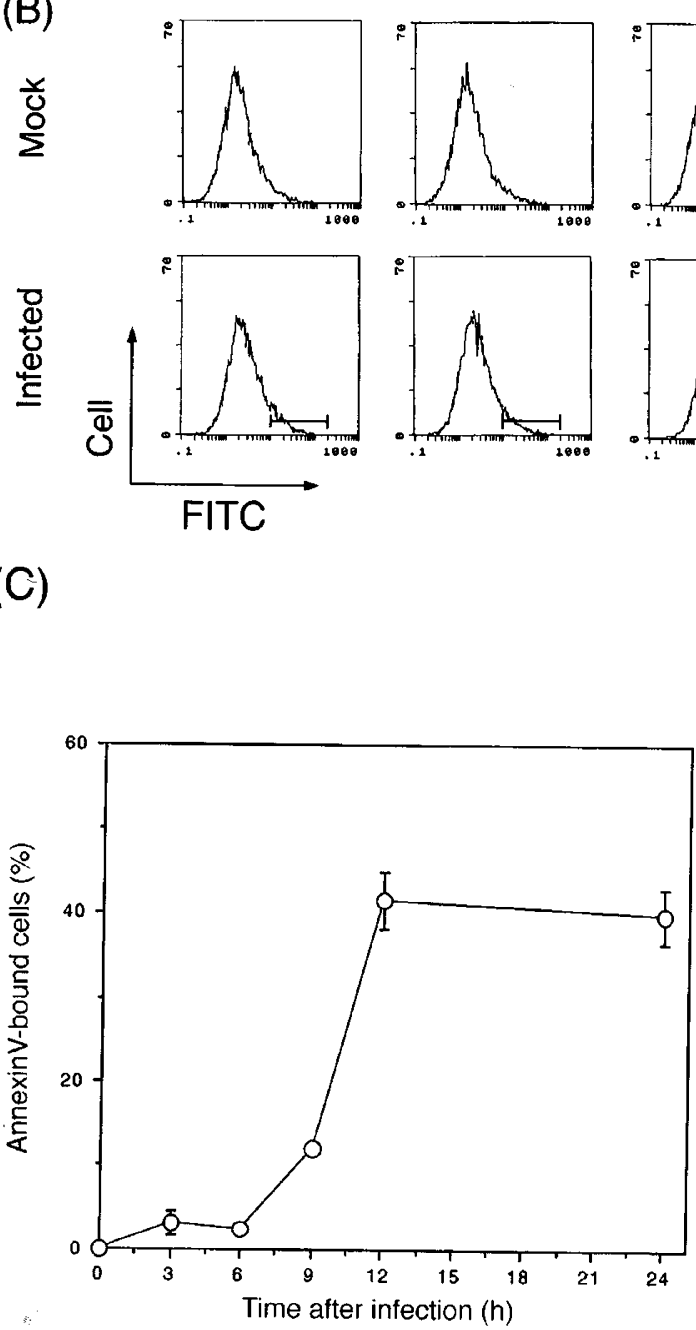

9
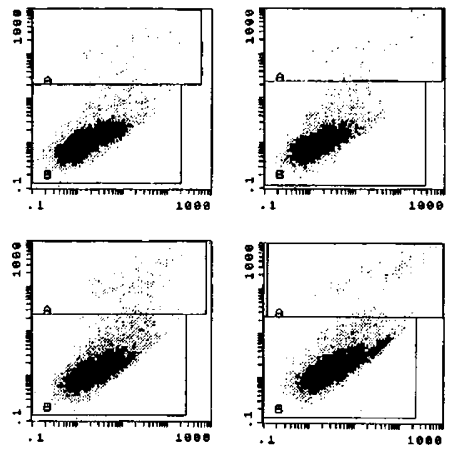

$\operatorname{limim}_{1000}$
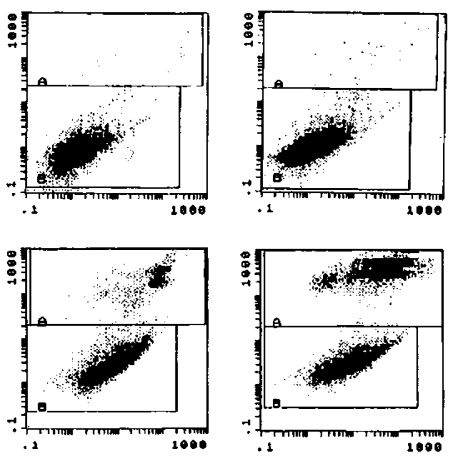

24
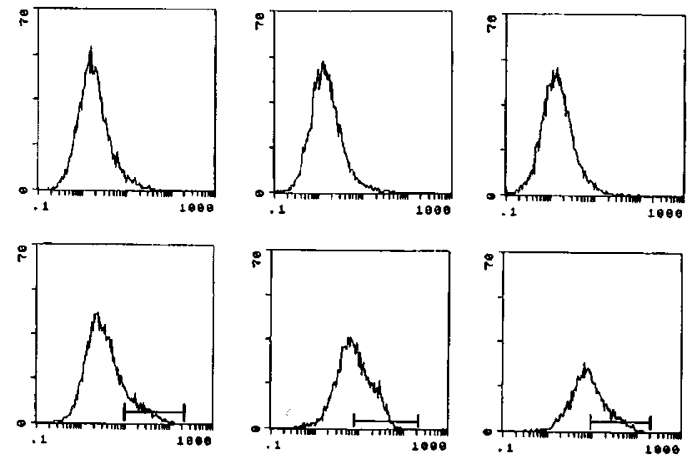

(D)

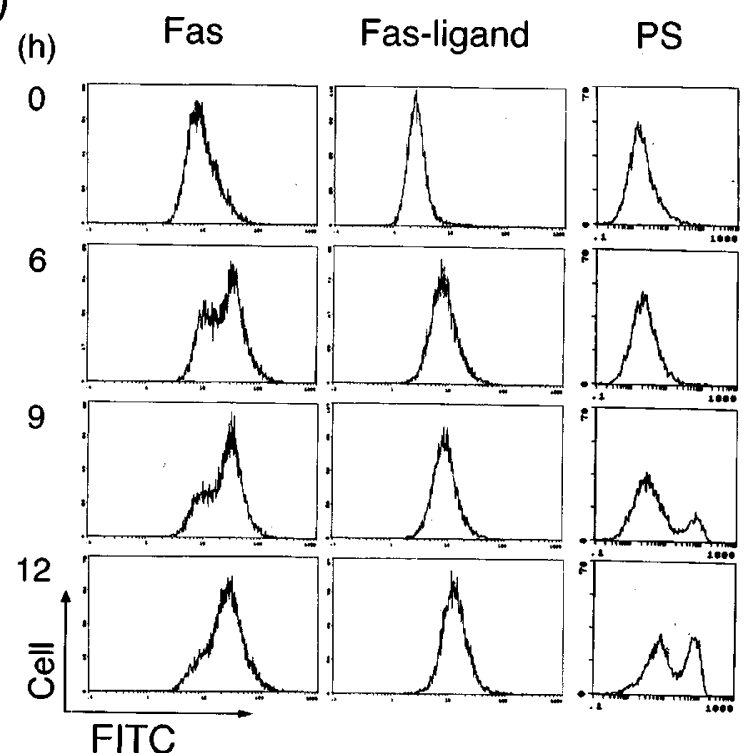

Figure 4 PS externalization in influenza virus-infected cells. The virus-infected and mock cells were treated with PI and FITC-labeled annexin V, and the presence of PS on the cell surface was determined by flow cytometry. (A) Signals from PI and FITC were determined. (B) The PI-negative cells were analyzed for the binding of annexin V. (C) The relative number of cells with more FITC signals, indicated with horizontal bars in (B), is shown with the mean and standard deviations from three independent experiments. (D) Simultaneous evaluation of Fas and Fas-ligand expression and PS externalization. Note that different virus stocks were used in (B) and (D) 
A

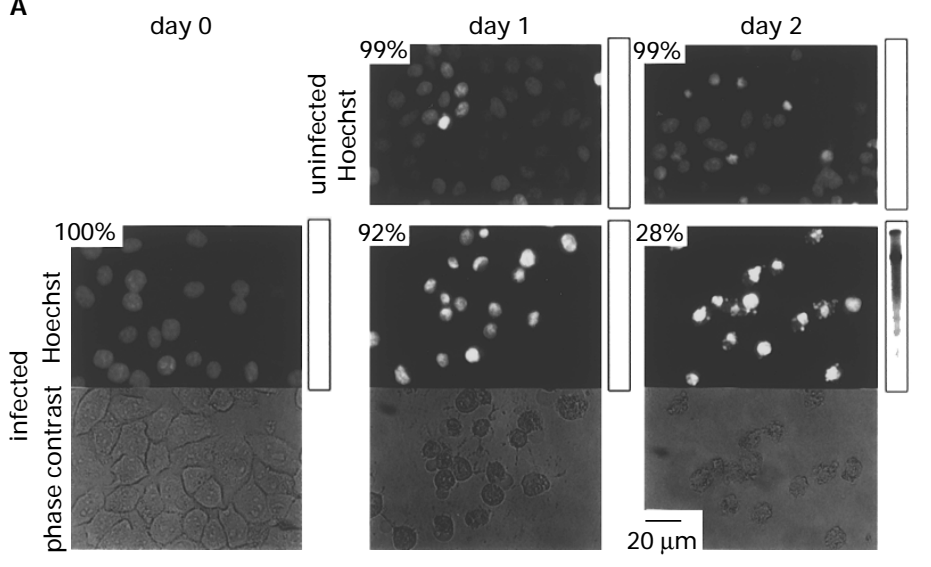

B

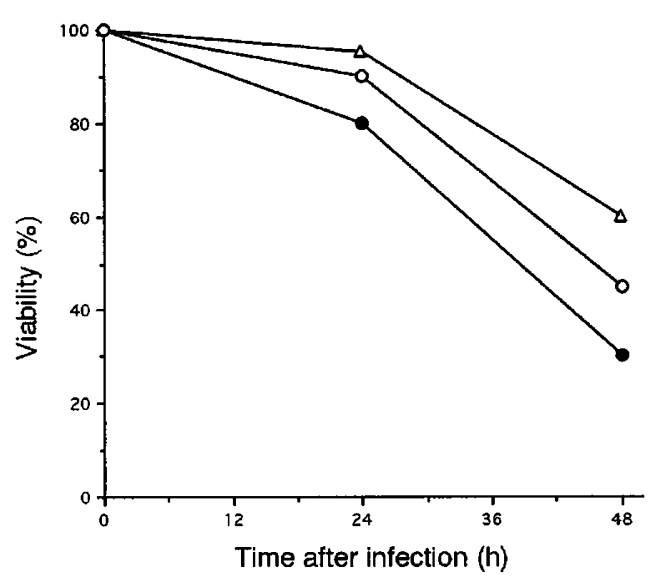

Figure 5 Apoptotic changes upon influenza virus infection. (A) Morphology, chromatin condensation, membrane permeability and DNA fragmentation in influenza virus-infected HeLa cells were determined. The cells were stained with Hoechst 33342 and examined by fluorescence (upper five panels) and phase-contrast (lower three panels) microscopy. The same cell populations were examined for membrane permeability by a trypan blue exclusion test and for DNA fragmentation; percentages of the cells with intact cell membranes are indicated in the inlets and autoradiograms of agarose gels are shown at the right of each panel. (B) Integrity of mitochondria and membrane permeability were determined. Cell viability in terms of trypan blue exclusion $(O)$, MTT conversion $(\triangle)$, and ${ }^{51} \mathrm{Cr}$ release $(\mathbf{O})$ is shown as the average from two independent experiments

\section{Externalization of phosphatidylserine on the surface of influenza virus-infected cells}

The above results suggested that apoptotic death of the influenza virus-infected cells is mediated by Fas and Fasligand. Cells undergoing Fas-mediated apoptosis show externalization of phosphatidylserine (PS) (Martin et al, 1995, 1996b; Conrad Liles et al, 1996), a phospholipid which is normally confined to the cytoplasmic leaflet of the membrane bilayer (Zachowski, 1993; Zwaal and Schroit, 1997), prior to other changes observed in apoptotic cells (Martin et al, 1995). To examine the occurrence of PS externalization upon influenza virus infection, cells were treated with fluorescein isothiocyanate (FITC)-labeled annexin $\mathrm{V}$ and propidium iodide $(\mathrm{PI})$, and analyzed in a flow cytometer. We observed two distinct cell populations of virusinfected cells in terms of the PI positivity (Figure 4A); it was presumed that the cells with less staining possessed intact plasma membranes, while the membrane of cells that were more intensely stained with $\mathrm{PI}$ were damaged. The ratio of $\mathrm{PI}$ positive cells increased as the culture period was prolonged, indicating the occurrence of cell death. The cells that were weakly stained with PI were examined for the binding of annexin $V$ (Figure 4B). The fluorescence intensity of a major peak began to shift at $9 \mathrm{~h}$ after infection, and the change was completed by $12 \mathrm{~h}$ (Figure 4C). These results indicated that PS externalization occurred synchronously in the influenza virus-infected cells after the induction of Fas and Fas-ligand (Figure 4D).

Other apoptotic changes such as chromatin condensation, DNA ladder formation, an increase of membrane permeability and inactivation of mitochondrial enzymes, all became evident at $24 \mathrm{~h}$ and later after infection (Figure 5). These results indicated that PS externalization precedes other apoptotic events examined so far. Influenza virus- infected cells thus seemingly behave like cells undergoing Fas-mediated apoptosis.

\section{Inhibition of apoptotic death of influenza virus- infected cells by antagonistic anti-Fas-ligand antibody}

We previously showed that the addition of anti-Fas monoclonal antibody clone ZB4 only partially inhibited apoptosis of influenza virus-infected cells (Takizawa et al, 1995). To further examine the involvement of Fas and Fasligand in the death of virus-infected cells, HeLa cells were infected with influenza virus in the presence of an anti-Fasligand monoclonal antibody, $4 \mathrm{H} 9$, that neutralizes the activity of Fas-ligand (Tanaka et al, 1996). The extent of cell death was determined in terms of PS externalization (Figure $6 \mathrm{~A}$ ) and permeabilization of the plasma membrane (Figure 6B). The addition of the antibody brought about a marked inhibition of both early and later apoptotic events caused by influenza virus infection, whereas the same amount of control IgG did not show any effect. Some apoptotic virus-infected cells were resistant to the Fas-ligand-antagonizing antibody, suggesting the occurrence of Fas-independent apoptosis. These results indicated that apoptosis of the influenza virus-infected cells is caused, though not completely, by Fas and Fas-ligand.

\section{Discussion}

We propose the following mechanism for apoptosis induction in influenza virus-infected cells; the virus-infected cells possess both Fas and Fas-ligand on the surface and apoptosis is induced when such cells attach to each other bringing about the interaction of Fas-ligand with its receptor Fas. Evidence has been accumulating that some stimuli activate the production of Fas-ligand which subsequently 

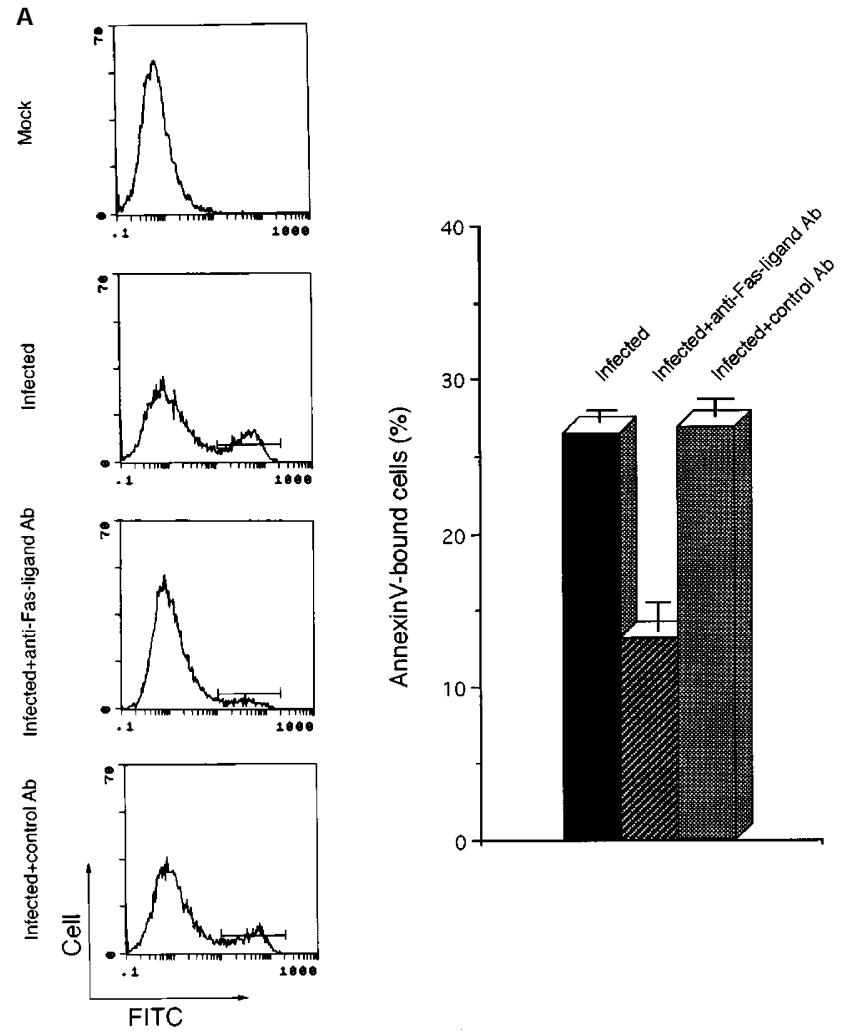

B

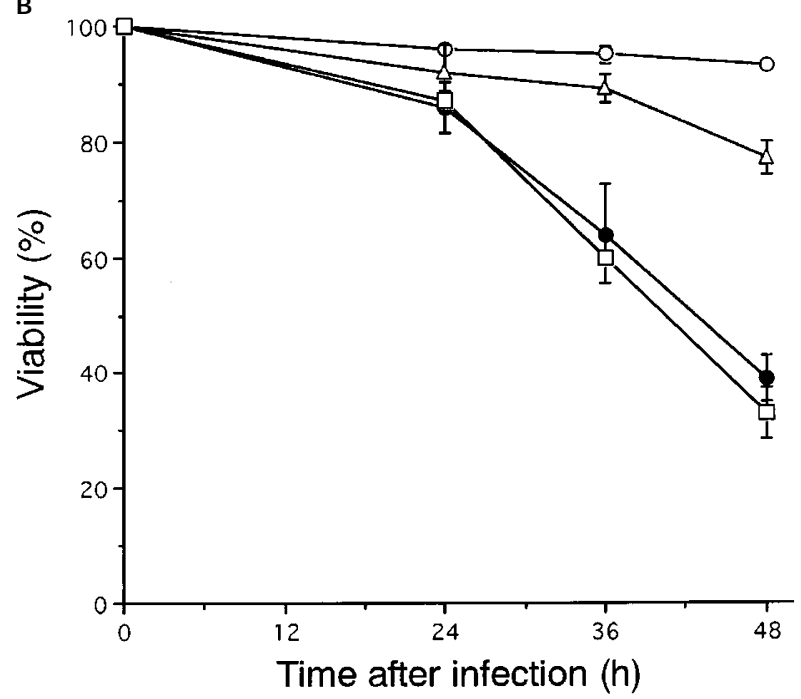

Figure 6 Inhibition of apoptosis of influenza virus-infected cells by $4 \mathrm{H} 9$ HeLa cells were infected with influenza virus in the presence of a saturated amount $(10 \mu \mathrm{g} / \mathrm{ml})$ of anti-human Fas-ligand monoclonal antibody clone $4 \mathrm{H} 9$ or control hamster IgG (Cappel Research Products, USA), and the extent of cel death was determined. (A) PS externalization in cells at $12 \mathrm{~h}$ after virus infection was determined by flow cytometry. A typical example is shown in the left panels, and the relative number of annexin V-bound cells, shown with horizontal bars, was shown at the right with the mean and standard deviations from three independent experiments. (B) Cell viability was determined by a trypan blue exclusion test. The percentages of trypan blue-negative (viable) cells are shown with the mean and standard deviations from three independent experiments. Symbols: (O), mock+no antibody; $(\mathbf{O})$, infected+no antibody; $(\triangle)$, infected+4H9; $\square)$, infected+control IgG leads to apoptosis of Fas-containing cells, such as antigenstimulated T-cells (Brunner et al, 1995; Dhein et al, 1995; Ju et al, 1995), anticancer drug-treated leukemia cells (Friesen et al, 1996), and human immunodeficiency virus-infected macrophages (Badley et al, 1996). Our results indicated that this is the case for influenza virus-infected cells.

Fas-ligand expression seemed to be de novo activated upon influenza virus infection whereas pre-existing Fas expression was stimulated. We anticipate that stimulation of Fas expression is needed for apoptosis induction in virusinfected cells since uninfected HeLa cells do not apoptose in the presence of either an agonistic anti-Fas antibody or Fas-ligand-expressing cells unless the cells are manipulated to over-produce Fas (unpublished observations). We have shown that transcription of the Fas-encoding gene is stimulated by a transcription factor called NF-IL6 that is most likely activated by double-stranded RNA-activated protein kinase upon influenza virus infection (Wada et al, 1995; Takizawa et al, 1996). The results shown in Figure 3 indicated that different mechanisms exist for the regulation of Fas and Fas-ligand expression. Our preliminary experiments showed that an increase in the amount of Fas-ligand upon influenza virus infection also occurs at the transcription level, and transcription regulation of the Fasligand-encoding gene is now under investigation.

Externalized PS has been shown to serve as a phagocytosis marker in some apoptotic cells (Savill et al, 1993; Zwaal and Schroit, 1997). It is thus of interest whether a change of membrane phospholipid localization in influenza virus-infected cells relates to heterophagic elimination of those cells.

\section{Materials and Methods \\ Cell culture and virus infection}

HeLa cells were maintained in Eagle's minimal essential medium (Nissui, Japan) supplemented with $10 \%$ fetal bovine serum at $37^{\circ} \mathrm{C}$ with $5 \% \mathrm{CO}_{2}$, and subconfluent monolayers were infected with SP626, a wild-type strain of the influenza A/Udorn/72 (H3N2) virus at a multiplicity of infection of three as described previously (Hatada et al, 1992). As a mock-infection control, HeLa cells were similarly treated without the virus.

\section{Flow cytometric analysis}

The virus- or mock-infected cells $\left(10^{6}\right)$ were treated with $1 \%$ paraformaldehyde for $30 \mathrm{~min}$ at room temperature and reacted with anti-human Fas monoclonal antibody clone UB2 (MBL, Japan) $(5 \mu \mathrm{g} /$ $\mathrm{ml}$ ) for $30 \mathrm{~min}$ on ice. The cells were then supplemented with FITCconjugated goat anti-mouse IgG (Immunotech, USA) $(1 \mu \mathrm{g} / \mathrm{ml})$ for $30 \mathrm{~min}$ on ice and analyzed in a flow cytometer (EPICS-XL, Coulter). For the analysis of cell surface Fas-ligand, the virus-infected cells were maintained in the presence of KB8301, an inhibitor of matrix metalloproteinase, to prevent proteolytic cleavage of the membranebound ligand (Kayagaki et al, 1995). The cells were fixed as above and reacted with anti-human Fas-ligand monoclonal antibody clone $4 \mathrm{H} 9$ (Tanaka et al, 1996) (MBL) $(5 \mu \mathrm{g} / \mathrm{ml})$ then treated with FITC-conjugated goat anti-hamster IgG (KPL, USA) $(10 \mu \mathrm{g} / \mathrm{ml})$. To examine the coexpression of Fas and Fas-ligand, the cells were simultaneously treated 
with UB2 and $4 \mathrm{H} 9$, then with tetramethyl rhodamine isothiocyanateconjugated goat anti-mouse IgG (Immunotech) $(10 \mu \mathrm{g} / \mathrm{ml})$ and FITCconjugated goat anti-hamster IgG and analyzed in a flow cytometer.

\section{Apoptosis assay}

PS exposure to the cell surface was monitored by flow cytometry, making use of fluorescence-labeled annexin $\mathrm{V}$ that specifically binds to PS (Koopman et al, 1994; Martin et al, 1996a). Influenza virusinfected HeLa cells were treated with FITC-labeled annexin V (Bender MedSystems, USA) and PI, and analyzed in a flow cytometer. The cells that were bound by annexin $\mathrm{V}$ but only weakly stained with PI, were taken as those with externalized PS. Cells having condensed chromatin were examined under a fluorescence/phase-contrast microscope (BX50, Olympus) after staining with Hoechst 33342. Whether or not the cells had inactive mitochondria was determined by a colorimetric enzyme assay with 3-(4,5-dimethylthiazol-2-yl)-2,5-a diphenyl tetrasolium bromide (MTT) according to the procedure of Mosmann (1983) using a commercial kit (Chemicon International Inc., USA). $A{ }^{51} \mathrm{Cr}$ release assay was employed to determine an increase of membrane permeability as described previously (Takizawa et al, 1993). Briefly, HeLa cells were incubated with $\mathrm{Na}_{2}{ }^{51} \mathrm{CrO}_{4}$ (New England Nuclear) for $1 \mathrm{~h}$, then infected with influenza virus. Samples of the medium were taken at the indicated time points and radioactivity was determined. DNA fragmentation assay was done according to the procedure of Tilly and Hsueh (1993). In brief, DNA was extracted from virus-infected cells, labeled with terminal deoxynucleotidyl transferase and $\left[\alpha{ }^{32}\right.$ P]ddATP (Amersham) and separated on a $2 \%$ agarose gel then autoradiographed.

\section{Poly(I)-poly(C) treatment}

HeLa cells were maintained in the presence of poly(I)-poly(C) $(0.1 \mathrm{mg} /$ $\mathrm{ml}$ ) (Pharmacia, Sweden) with no serum at $37^{\circ} \mathrm{C}$ for $24 \mathrm{~h}$. The amounts of cell surface Fas and Fas-ligand were then determined by flow cytometry as described above.

\section{Acknowledgements}

We thank $E$ Hatada and $R$ Fukuda for influenza virus, and $K$ Yoshino of Kanebo Ltd. for KB8301. This work was supported by a grant-in-aid for scientific research from the Minsitry of Education, Science and Culture of Japan and by a grant from the Yamanouchi Foundation for Research on Metabolic Disorders.

\section{References}

Badley AD, McElhinny JA, Leibson PJ, Lynch DH, Alderson MR and Paya CV (1996) Upregulation of Fas ligand expression by human immunodeficiency virus in human macrophages mediates apoptosis of uninfected T lymphocytes. J. Virol. 70: $199-206$

Brunner T, Mogil RJ, LaFace D, Yoo NJ, Mahboubi A, Echeverri F, Martin SJ, Force WR, Lynch DH, Ware CF and Green DR (1995) Cell-autonomous Fas (CD95)/ Fas-ligand interaction mediates activation-induced apoptosis in T-cell hybridomas. Nature 373: 441-444

Conrad Liles W, Kiener PA, Ledbetter JA, Aruffo A and Klebanoff SJ (1996) Differential expression of Fas (CD95) and Fas ligand on normal human phagocytes: implication for the regulation of apoptosis in neutrophils. J. Exp. Med. 184: $429-440$

Dhein J, Walczak H, Bäumler C, Debatin K-M and Krammer PH (1995) Autocrine Tcell suicide mediated by APO-1/(Fas/CD95). Nature 373: 438-441

Fesq H, Bacher M, Nain Mand Gemsa D (1994) Programmed cell death (apoptosis) in human monocytes infected by influenza A virus. Immunobiology 190: 175-182
Friesen C, Herr I, Krammer PH and Debatin K-M (1996) Involvement of the CD95 (APO-1/Fas) receptor/ligand system in drug-induced apoptosis in leukemia cells. Nature Med. 2: $574-577$

Hatada E, Takizawa T and Fukuda R (1992) Specific binding of influenza A virus NS1 protein to the virus minus-sense RNA in vivo. J. Gen. Virol. 73: 17-25

Hinshaw VG, Olsen CW, Dybdahl-Sissoko N and Evans D (1994) Apoptosis: a mechanism of cell killing by influenza A and B viruses. J. Virol. 68: 3667-3673

Ju S-T, Panka DJ, CuiH, Ettinger R, El-Khatib M, Sherr DH, StangerBZand MarshakRothstein A (1995) Fas(CD95)/FasL interactions required for programmed cell death after T-cell activation. Nature 373: $444-448$

Kayagaki N, Kawasaki A, Ebata T, Ohmoto H, Ikeda S, Inoue S, Yoshino K, Okumura Kand Yagita H (1995) Metalloproteinase-mediated release of human Fas ligand. J. Exp. Med. 182: 1777-1783

Koopman G, Reutelingsperger CPM, Kuijten GAM, Keehnen RMJ, Pals ST and van Oers MHJ (1994) Annexin V for flow cytometric detection of phosphatidylserine expression on B cells undergoing apoptosis. Blood 84: 1415-1420

Martin SJ, Reutelingsperger CPM, McGahon AJ, Rader JA, van Schie RCAA, LaFace DM and Green DR (1995) Early redistribution of plasma membrane phosphatidylserine is a general feature of apoptosis regardless of the initiating stimulus: inhibition by overexpression of Bcl-2 and Abl. J. Exp. Med. 182: 15451556

Martin SJ, ReutelingspergerCPMand Green DR (1996a) Annexin V: a specific probe for apoptotic cells. In Techniques in apoptosis, In Cotter TG and Martin SJ, (London: Portland Press) pp. 107-119

Martin SJ, Finucane DM, Amarante-Mendes GP, O'Bien GA and Green DR (1996b) Phosphatidylserine externalization during CD95-induced apoptosis of cells and cytoplasts requires ICE/CED-3 protease activity. J. Biol. Chem. 271: $28753-$ 28756

Mori I, Komatsu T, Takeuchi K, Nakakuki K, Sudo M and Kimura Y (1995) In vivo induction of apoptosis by influenza virus. J. Gen. Virol. 76: 2869-2873

Mosmann T (1983) Rapid colorimetric assay for cellular growth and survival: application to proliferation and cytotoxicity assays. J. Immunol. Methods 65:5563

Nagata S (1997) Apoptosis by death factor. Cell 88: 355-365

Nakanishi Y (1995) Regulation of apoptosis in virus-infected cells. Tiss. Cult. Res. Commun. 14: 127-132

Peter ME, Kischkel FC, Hellbardt S, Chinnaiyan AM, Krammer PH and Dixit VM (1996) CD95 (APO-1/Fas)-associating signaling proteins. Cell Death Differ. 3: $161-170$

Savill J, Fadok V, Henson P and Haslett C (1993) Phagocyte recognition of cells undergoing apoptosis. Immunol. Today 14: 131-136

Takizawa T, Ohashi K and Nakanishi Y (1996) Possible involvement of doublestranded RNA-activated protein kinase in cell death by influenza virus infection. J. Virol. 70: 8128-8132

Takizawa T, Fukuda R, Miyawaki T, Ohashi K and Nakanishi Y (1995) Activation of the apoptotic Fas antigen-encoding gene upon influenza virus infection involving spontaneously produced beta-interferon. Virology 209: 288-296

Takizawa T, Matsukawa S, Higuchi Y, Nakamura S, Nakanishi Y and Fukuda R (1993) Induction of programmed cell death (apoptosis) by influenza virus infection in tissue culture cells. J. Gen. Virol. 74: 2347-2355

Tanaka M, Suda T, Haze K, Nakamura N, Sato K, Kimura F, Motoyoshi K, Mizuki M, Tagawa S, Ohga S, Hatake K, Drummond AH and Nagata S (1996) Fas ligand in human serum. Nature Med. 2: 317-322

Tanaka M, Suda T, Takahashi T and Nagata S (1995) Expression of the functional soluble form of human Fas ligand in activated lymphocytes. EMBO J. 14:11291135

Teodoro JG and Branton PE (1997) Regulation of apoptosis by viral gene products. J. Virol. 71 : $1739-1746$

Tilly JL and Hsueh AJW (1993) Microscale autoradiographic method for the qualitative and quantitative analysis of apoptotic DNA fragmentation. J. Cell. Physiol. 154: 519-526

Wada N, Matsumura M, Ohba Y, Kobayashi N, Takizawa T and Nakanishi Y (1995) Transcription stimulation of Fas-encoding gene by nuclearfactor for interleukin-6 expression upon influenza virus infection. J. Biol. Chem. 270: 18007-18012

Zachowski A (1993) Phospholipids in animal eukaryotic membranes: transverse asymmetry and movement. Biochem. J. 294: 1-14

Zwaal RFA and Schroit AJ (1997) Pathophysiologic implications of membrane phospholipid asymmetry in blood cells. Blood 89: 1121-1132 